\title{
ASSESSMENT OF EDUCATIONAL PROCESS REGIONAL FACTORS' AND TENSION INFLUENCE ON STUDENTS' BLOODSTREAM SYSTEM AND HOMEOSTASIS VEGETATIVE CHARACTERISTICS
}

Gajnullin R.A. ${ }^{1}$, Isaev A.P. ${ }^{2}$, Korableva I.B. ${ }^{3}$

${ }^{1}$ Bashkir State Medical University

${ }^{2}$ South Ural State University Institute of Sport, Tourism and Service

${ }^{3}$ South Ural State University Institute of Sport, Tourism and Service

\begin{abstract}
Purpose: to study influence of regional factors and intensive educational process on cardio-haemodynamic and vegetative characteristics in conditions of individual differentiated classes. Material: in the research 80 student (of 17-18 years' age) participated; they were divided into group of the tested ( $\mathrm{n}=40$ ) and group of comparison $(\mathrm{n}=40)$. Results: we showed physiological influence on bloodstream regulation and weakening of activity in conditions of individual-differentiated classes. The content of programs of informational, sports-health related, physical culture and prophylaxis measures resulted in students' different speed characteristics (in bloodstream links and in its regulation). In conditions of annual educational process the students had balance of sympathetic and para-sympathetic regulation of central and periphery bloodstream. It depends on weather factors of year seasons, on examination sessions. Conclusions: in conditions of educational process adaptationcompensatory shifts are conditioned by dominating segmental regulation with participation of bloodstream links and regulatory supra-segmental influences. We also observed manifestation of influence of separate autonomous regulation factors.
\end{abstract}

Key words: informational, loads, season, regional factors, bloodstream, vegetative maintenance.

\section{Introduction}

The problem of students' functional state assessment in conditions of modern educational process acquires still higher social-biological and medical importance. Constantly changing algorithms of reformation of education create obstacles to planned organization of university's educational process and worsen health $[1,3,5]$. In this connection there appears demand in searching new technologies of psycho-physiological potential's improvement as well as health level.

One of such directions can be increase of students' health level through reduction of regional factors' and intensive educational process's negative influence on cardio-haemo-dynamic and vegetative characteristics of organism. Basing on it we can assume that different links of central and periphery haemo-dynamic manifest relatively autonomously and their bio-rhythms manifest depending on season, fulfilling main function of tissues supply with $\mathrm{O}_{2}$ [20, pg. 65].

Besides, we can assume that students' blood circulation system changes substantially in conditions of background studies and organism's responses to functional tests. Prevalence of sympathetic regulation over parasympathetic permits to speak about weakness of vegetative processes in conditions of intensive educational process and initially low motor functioning $[12,16,19]$. Initially low students' organism's resistance causes activation of sympathetic regulation links and tension of adaptation-compensatory processes, resulting in mobilization of segmental cortex-subcortex regulation [15, pg. 34].

It was found that extremely intensive educational process in conditions of half-year increased motor functioning causes changes in bloodstream system mainly at level of tendency [6, 7, 9]. Besides, we registered physiological changes in decrease of quantity of students with bloodstream disorders, with hyper-kinetic blood circulation type, with negative reactions to orthostatic test [8]. In other research there was shown positive role of fitness technologies in increase of students' haemo-dynamic's functional state and their health improvement [11]. It was noted that change of cardiovascular system's (CVS) indicators can witness about prolonged impact of stresstension. Such impact is a result of educational and season factors as well as caused by sensibilization [10, pg. 54].

In our previous works $[5,6,7]$ we substantiated application of technologies of local-regional muscular endurance training in combination with stretching, relaxation and special exercises. We showed effectiveness of

(c) Gajnullin R.A., Isaev A.P., Korableva I.B., 2016 doi:10.15561/20755279.2016.0401 
influence of scientifically substantiated data, which condition effective adaptation's formation. It was found that already during 6 months of individual-differentiated and group classes the quantity of the following students decreased:

- Students with problems in cardio-vascular system (CVS) - from 31.92 to $13.82 \%$;

- With hyper-kinetic type of bloodstream - from 62.50 to $24.82 \%$;

- With negative reaction to change of position "lying-standing" - from 52.52 to $28.65 \%$.

The received data proved physiological role of aerobic motor functioning (MF) (fitness) and other kinds of motor actions (MA). Besides, it was found that amphotonic level gradually reduced, depending on seasons of year, while sympathicotonia level - increased. Accordingly, para-sympathetic impacts weakened. It resulted in balance of ergotropic and inotropic factors in myocardium. Vegetative responsiveness of students' organism witnessed about increase of quantity of sympathicotonic and a-sympathicotonic reactions in winter and in spring. Thus, we found tensions in system of vegetative homeostasis and mismatch in responsive reactions. It witnesses about level of psycho-physiological losses, which, sometimes, exceed regulatory potentials of students' organism.

Hypothesis: it is assumed that information loads of modern educational process, regional natural-climatic factors, environmental pollution, low motor functioning (MF), irrational eating can cause physiological tension and generalized adaptation syndrome (GAS) with specific groups of adaptation reactions.

The purpose of the research is to analyze impact of regional factors and education process's tension on bloodstream regulation and vegetative indicators of students.

\section{Material and methods}

Participants: in the research 80 students (of 17-18 years' age) participated; they were divided into group of the tested $(\mathrm{n}=40)$ and group of comparison $(\mathrm{n}=40)$.

Organization of the research: the participants in the group of tested were trained 5 times a week in conditions of increased MF (kickboxing, swimming and boxing). The group of comparison was trained 3 times a week: students attended physical culture curriculum classes. In the group of tested accent was made on development of local-regional muscular endurance and specialization in the chosen kind of sports. As means of training they practiced power training, stretching, swimming twice a week. Besides, massage was applied. The group of comparison was trained as per academic traditional program. In days off students of this group participated in outdoor games, hiking.

Stress-tension of the participants was created by combined social-ecological influences and examination sessions.

Indicators of bloodstream regulation and vegetative indicators in the researched groups were registered by diagnostic installation MARG 10-01 (for registration of central and periphery haemo-dynamic indicators we used bio-impedance tetra-polar reo-printing on the base of computer system, produced by "Microlux"). The system was recommended for application in medicine by protocol №ROSS.RU.AU. 45.BOO 21, dated 28.11.2002. (See tables 1, 2).

Statistical analysis: statistical processing of the data was fulfilled with the help of SPSS.12 programs. We used Freedman's criterion; interpretation of season changes was fulfilled by recommendations of A.M. Wayne [2, pg. 54].

\section{Results of the researches}

Creation of specialized project in the frames of physical education and mass sports of medical university students requires the following approaches:

- Integrative character of system of motivation;

- Purposefulness;

- Theoretical, informational enrichment;

- Practical support of psycho-physiological potential, physical health and mental workability.

For this purpose physical culture department of Bashkir State Medical University (BSMU) created information block. Besides, they worked out the system of Republican level competitions, in which students and graduates of the university participate as well as practicing medical doctors. At department specialized courses for combined trainings were formed. 
When working out academic programs the department was guided by idea that the content of trainings shall be oriented on creation of students' general and professional culture, development of adaptation to environmental conditions.

According to requirements of governmental educational standards for discipline "Physical culture" the students of medical faculties shall have:

- Knowledge about social health related effect of physical culture in training for professional functioning (healthy life style, prophylaxis, rehabilitation);

- Methods of physical perfection and self-education, technologies of training other people.

Besides, these students shall have skills in non-medical health improvement and be able to consult about choice of health related activity. Future medical doctor shall be competent in subjects of therapeutic and rehabilitation physical culture, therapeutic massage, manual therapy.

Lecture material was enriched with subjects: "Social-biological integration in health formation and assessment", "Health related effects of behavior". These lectures deliver information about influence of different motor functioning on muscular skeletal apparatus, nervous-muscular and organism's cardio-respiratory systems. Modern classification of professional-applied physical training, health related systems are offered. Orientation of training process, volume and intensity of loads are determined. In conditions of methodic classes, technologies of motor skills' development and their combinations with fitness-aerobic, oriental physical exercises, stretching, relaxation, affirmations and psycho-regulation practice is determined.

The changes of cardio-haemo-dynamic in conditions of educational process were analyzed with the help of Freedman's criterion (see table 1). In the group of the tested we registered increase of the following:

- Integral index (Pi) of cardio-vascular system (CVS) in spring and in autumn;

- Heart beats rate (HBR), segment ST of electro-cardiogram (ECG) - in autumn and in winter;

- Saturation, systolic blood pressure (SBP) - in summer and in autumn;

- Index of sympathetic activity - in autumn and in winter;

- Amplitude of small vessels pulsation - in winter and spring;

- Diastolic blood pressure (DBP) and mean dynamic pressure (MD) - in summer and in spring;

- Amplitude of aorta pulsation - in summer and in spring;

- Stroke volumes (SV) - in autumn and in winter;

- Heater index (Hi), of diastolic wave of heart filling, index of $\mathrm{O}_{2}$ delivery to tissues - in summer and in spring;

- Ejection fraction - in spring and in winter of minute blood volume (MBV).

The presented in table 1 parameters witness that vegetative regulation is of sympathetic orientation in its impact on central bloodstream, including large and small circles of blood circulation, contractility of myocardium, venouis age. In conditions of central bloodstream mobilization Pi, MD, saturation and SV haemo-dynamic indicators manifested dominantly.

Table 1. Season fluctuations of cardio-haemo dynamic by Freedman's criterion in the group of tested students $(n=40)$

\begin{tabular}{|c|c|c|c|c|c|c|c|c|c|c|}
\hline \multirow[b]{2}{*}{ Season } & \multicolumn{10}{|l|}{ Indicators } \\
\hline & $\begin{array}{l}\text { Integral } \\
\text { index of } \\
\text { condition }\end{array}$ & $\begin{array}{l}\text { HBR, } \\
\text { Heart } \\
\text { beats } \\
\text { rate }\end{array}$ & $\begin{array}{l}\text { ST } \\
\text { segment } \\
\text { of ECG }\end{array}$ & $\begin{array}{l}\mathrm{SPO}_{2} \\
\text { saturatio }\end{array}$ & $\begin{array}{l}\text { TOEA. } \\
\text { Amplitude } \\
\text { of small } \\
\text { vessels' } \\
\text { pulsation }\end{array}$ & $\begin{array}{l}\text { NISP, } \\
\text { Systolic } \\
\text { BP }\end{array}$ & $\begin{array}{l}\text { NISD, } \\
\text { Diastolic } \\
\text { BP }\end{array}$ & $\begin{array}{l}\text { WSBR, } \\
\text { Mean } \\
\text { dynamic } \\
\text { pressure }\end{array}$ & RR & $\begin{array}{l}\text { S, } \\
\text { Index of } \\
\text { sympathetic } \\
\text { activity }\end{array}$ \\
\hline Spring & 2.79 & 2.49 & 2.45 & 2.22 & 2.62 & 2.42 & 2.60 & 2.84 & 2.65 & 2.09 \\
\hline Summer & r2.16 & 2.36 & 2.29 & 2.68 & 2.43 & 2.72 & 2.58 & $2, .48$ & 2.42 & 2.43 \\
\hline Autumn & 2.59 & 2.62 & 2.60 & 2.57 & 2.32 & 2.50 & 2.48 & 2.37 & 2.60 & 2.94 \\
\hline Winter & 2.46 & 2.53 & 2.66 & 2.53 & 2.62 & 2.36 & 2.35 & 2.31 & 2.33 & 2.53 \\
\hline
\end{tabular}


Chi-

\begin{tabular}{|c|c|c|c|c|c|c|c|c|c|}
\hline $\begin{array}{l}\text { square } \\
\left(x^{2}\right)\end{array}$ & 5.87 & 1.023 & 2.375 & 3.616 & 1.757 & 2.065 & 4.048 & 5.675 & 2.7971.,137 \\
\hline \multirow[t]{2}{*}{$\begin{array}{l}\text { Asump- } \\
\text { Sig }\end{array}$} & 0.117 & 0.796 & 0.498 & 0.306 & 0.624 & 0.559 & 0.778 & 0.129 & 0.4240 .017 \\
\hline & \multicolumn{9}{|l|}{ Indicators } \\
\hline Season & $\begin{array}{l}\text { TrxA, } \\
\text { amplitude } \\
\text { of aorta } \\
\text { pulsation }\end{array}$ & $\begin{array}{l}\text { SV, } \\
\text { Stoke } \\
\text { volume }\end{array}$ & $\begin{array}{l}\mathrm{Hi}, \\
\text { Heater } \\
\text { index }\end{array}$ & & $\begin{array}{l}E F \text {, } \\
\text { ejection } \\
\text { fraction }\end{array}$ & $\begin{array}{l}\text { FW, } \\
\text { Diastolic } \\
\text { wave }\end{array}$ & $\begin{array}{l}\text { CO, } \\
\text { MBV }\end{array}$ & $\begin{array}{l}\mathrm{Ci}, \\
\text { Heart } \\
\text { index }\end{array}$ & $\begin{array}{l}\mathrm{DiO}_{2} \text {, } \\
\text { Index of } \\
\text { oxygen supply } \\
\text { to tissues }\end{array}$ \\
\hline Spring & 2.64 & 2.29 & 2.46 & & 2.73 & 2.49 & 2.34 & 2.47 & 2.59 \\
\hline Summer & r.65 & 2.37 & 2.73 & & 2.46 & 2.76 & 2.53 & 2.64 & 2.62 \\
\hline Autumn & 2.47 & 2.88 & 2.41 & & 2.12 & 2.29 & 2.49 & 2.41 & 2.41 \\
\hline Winter & 2.24 & 2.46 & 2.40 & & 2.70 & 2.46 & 2.64 & 2.48 & 2.38 \\
\hline Chi- & & & & & & & & & \\
\hline $\begin{array}{l}\text { square, } \\
\left(x^{2}\right)\end{array}$ & 3.111 & 5.846 & 1.967 & & 6.965 & 3.245 & 1.362 & 0.854 & 1.909 \\
\hline $\begin{array}{l}\text { Asump- } \\
\text { Sig }\end{array}$ & 0.375 & 0.119 & 0.579 & & 0.073 & 0.370 & 0.715 & 0.836 & 0.751 \\
\hline
\end{tabular}

In group of comparison (see table 2) indicators of blood circulation in order of intervals significance are given in the following way: MBV, heart index, HBR. Integral index varied in the range of PS impacts. HBR and ST segment of ECG characterized physiological state of myocardium against the background of reduced saturation. Index of sympathetic activity witnessed about balance of vegetative (S and PS) regulation. Heater index (Hi) shows increased contractility of myocardium. These data prove increased significance of ejection fraction. Indicators of venous age were below level of control.

In ranking order season fluctuations of bloodstream were located as follows:

- Heart rhythm, MD, SBP, amplitude of aorta reo-waves, S, Pi - in spring and in summer;

- Index of $\mathrm{O}_{2}$ supply to tissues $(\mathrm{Ci})$, ejection fraction - in spring and in winter;

- SV (stroke volume), DWHF (diastolic wave of heart filling) - in spring and in autumn;

- Amplitude of aorta pulsation, saturation, ST segment of ECG, HBR - in summer and in autumn;

- MBV, Hi - in winter and in autumn; amlitude of vessels' reo-waves - in winter and in summer.

The quantity of adaptation components in comparison group was bigger than in the group of the tested.

Table 2. Season fluctuations of students' cardio-respiratory indicators by Freedman's criterion (group of comparison, $\mathrm{n}=40$ )

\begin{tabular}{|c|c|c|c|c|c|c|c|c|c|}
\hline $\begin{array}{l}\text { Indicators, } \\
\text { season }\end{array}$ & $\begin{array}{l}\mathrm{DiO}_{2} \\
\text { Index of } \\
\text { oxygen } \\
\text { supply to } \\
\text { tissues }\end{array}$ & $\begin{array}{l}\text { Heart } \\
\text { index }\end{array}$ & $\begin{array}{l}\mathrm{CO}, \\
\mathrm{MBV}\end{array}$ & $\begin{array}{l}\text { FW, } \\
\text { Diastolic } \\
\text { wave }\end{array}$ & $\begin{array}{l}\text { EF, } \\
\text { Ejection } \\
\text { fraction }\end{array}$ & $\begin{array}{l}\mathrm{Hi}, \\
\text { Heater } \\
\text { index }\end{array}$ & $\begin{array}{l}\text { SV, } \\
\text { Stoke } \\
\text { volume }\end{array}$ & $\begin{array}{l}\text { TrxA, } \\
\text { Amplitude } \\
\text { of aorta } \\
\text { pulsation }\end{array}$ & $\begin{array}{l}\text { S, } \\
\text { Index of } \\
\text { sympathetic } \\
\text { activity }\end{array}$ \\
\hline Spring & 2.57 & 2.82 & 2.44 & 2.34 & 2.65 & 2.42 & 2.64 & 2.59 & 2.71 \\
\hline Summer & 2.35 & 2.34 & 2.17 & 2.68 & 2.51 & 2.38 & 2.47 & 2.69 & 2.53 \\
\hline Autumn & 2.52 & 2.22 & 2.65 & 2.82 & 2.32 & 2.49 & 2.50 & 2.24 & 2.38 \\
\hline Winter & 2.55 & 2.61 & 2.75 & 2.16 & 2.52 & 2.72 & 2.40 & 2.49 & 2.39 \\
\hline $\begin{array}{l}\text { Chi-square } \\
\left(x^{2}\right)\end{array}$ & 0.858 & 6.742 & 5.897 & 8.148 & 1.619 & 2.035 & 0.880 & 3.189 & 2.128 \\
\hline Asump-Sig & 0.836 & 0.081 & 0.177 & 0.040 & 0.655 & 0.565 & 0.830 & 0.363 & 0.546 \\
\hline
\end{tabular}




\begin{tabular}{|c|c|c|c|c|c|c|c|c|c|}
\hline $\begin{array}{l}\text { Indicators, } \\
\text { season }\end{array}$ & $\mathbf{R R}$ & $\begin{array}{l}\text { WSBR, } \\
\text { mean } \\
\text { dynamic } \\
\text { pressure }\end{array}$ & $\begin{array}{l}\text { NISP, } \\
\text { Diastolic BP }\end{array}$ & $\begin{array}{l}\text { NISD, } \\
\text { Systolic BP }\end{array}$ & $\begin{array}{l}\text { TOEA, } \\
\text { Amplitude } \\
\text { of small } \\
\text { vessels' } \\
\text { pulsation }\end{array}$ & $\begin{array}{l}\mathrm{SPO}_{2}, \\
\text { Saturat } \\
\text { on }\end{array}$ & $\begin{array}{l}\text { ST - } \\
\text { segme } \\
\text { int of } \\
\text { ECG }\end{array}$ & $\begin{array}{l}\text { HBR, } \\
\text { Heart } \\
\text { beats rate }\end{array}$ & $\begin{array}{l}\mathrm{Pi}, \\
\text { Integral } \\
\text { index of CVS } \\
\text { condition }\end{array}$ \\
\hline Spring & 2.58 & 2.55 & 2.53 & 2.66 & 2.11 & 2.49 & 2.48 & 2.25 & 2.60 \\
\hline Summer & 2.64 & 2.58 & 2.59 & 2.40 & 2.52 & 2.73 & 2.58 & 2.63 & 2.56 \\
\hline Autumn & 2.55 & 2.32 & 2.40 & 2.54 & 2.44 & 2.54 & 2.64 & 2.76 & 2.34 \\
\hline Winter & 2.23 & 2.54 & 2.48 & 2.41 & 2.93 & 2.24 & 2.30 & 2.36 & 2.49 \\
\hline $\begin{array}{l}\text { Chi-square } \\
\left(x^{2}\right)\end{array}$ & 4.049 & 1.713 & 0.633 & 1.388 & 9.737 & 3.865 & 1.942 & 4.969 & 1.158 \\
\hline Asump-Sig & 0.256 & 0.634 & 0.889 & 0.708 & 0.021 & 0.276 & 0.585 & 0.174 & 0.763 \\
\hline
\end{tabular}

In table 3 we present dynamic of students' vegetative supply in conditions of increased MF.

Table 3. Vegetative homeostasis of students in annual educational process, $n=80$

\begin{tabular}{|c|c|c|c|c|c|}
\hline \multirow{2}{*}{ Indicators } & \multirow{2}{*}{ Description } & \multicolumn{4}{|l|}{ Seasons } \\
\hline & & Summer & Autumn & Winter & Spring \\
\hline \multirow{3}{*}{$\begin{array}{l}\text { Background } \\
\text { vegetative status }\end{array}$} & Amphotonic & 76.00 & 75.20 & 72.50 & 70.20 \\
\hline & Sympathicotonia & 5.20 & 8.00 & 12.50 & 15.80 \\
\hline & Vagotonia & 18.80 & 16.80 & 15.00 & 14.00 \\
\hline \multirow{3}{*}{$\begin{array}{l}\text { Vegetative } \\
\text { responsiveness }\end{array}$} & Normotonic & 90.60 & 90.20 & 68.80 & 64.70 \\
\hline & Hyper-Sympathicotonic & 5.20 & 5.60 & 21.20 & 23.00 \\
\hline & A- Sympathicotonia & 4.20 & 4.20 & 10.00 & 12.30 \\
\hline Vegetative & Sufficient & 91.80 & 89.20 & 80.70 & 76.30 \\
\hline provisioning of & Excessive & 5.00 & 4.60 & 12.30 & 14.70 \\
\hline activity & Insufficient & 4.20 & 6.20 & 7.00 & 9.00 \\
\hline Period of & Normal & 88.80 & 86.40 & 80.20 & 78.60 \\
\hline restoration & Prolonged & 11.20 & 13.60 & 19.80 & 21.40 \\
\hline
\end{tabular}

In table 4 we give changes of indicators of students' central haemo-dynamic in increased MF in different seasons in conditions of educational process.

Table 4. Indicators of students' central haemo-dynamic in different seasons

\begin{tabular}{lllllll}
\hline $\begin{array}{l}\text { Seasons, } \\
\text { probability of } \\
\text { differences }\end{array}$ & HBR, bpm & SV, ml & $\begin{array}{l}\text { Ejection } \\
\text { fraction, } \%\end{array}$ & Heater index & $\begin{array}{l}\text { Venous } \\
\text { return, MoM }\end{array}$ & $\begin{array}{l}\text { MBV, } \\
\text { I/min }\end{array}$ \\
\hline Summer (1) & $67.20 \pm 1.34$ & $70.92 \pm 2.26$ & $60.23 \pm 0.36$ & $16.52 \pm 0.81$ & $47.90 \pm 1.28$ & $4.77 \pm 0.34$ \\
Autumn (2) & $69.80 \pm 1.96$ & $68.80 \pm 2.22$ & $59.87 \pm 0.89$ & $15.43 \pm 0.99$ & $44.52 \pm 1.34$ & $4.80 \pm 0.56$ \\
Winter (3) & $72.32 \pm 2.54$ & $65.69 \pm 2.03$ & $57.20 \pm 0.97$ & $19.87 \pm 1.02$ & $41.22 \pm 1.20$ & $4.58 \pm 0.29$ \\
Spring (4) & $74.68 \pm 2.70$ & $63.29 \pm 2.01$ & $56.72 \pm 1.03$ & $22.20 \pm 1.46$ & $39.33 \pm 1.66$ & $4.73 \pm 0.36$ \\
P1-P2 & & & & $<0.01$ & & $<0.05$ \\
P1-P3 & & & $<0.01$ & $<0.05$ & $<0.05$ & \\
P2-P4 & & & $<0.01$ & $<0.05$ & & \\
P3-P4 & & & $<0.05$ & & $<0.01$ & \\
P1-P4 & $<0.05$ & $<0.01$ & $<0.01$ & $<0.01$ &
\end{tabular}

Bloodstream changes manifest the most brightly in conditions of orthostatic balance (see table 5). 
Table 5. Change of students' blood circulation indicators under influence of orthostatic tests in different seasons

\begin{tabular}{|c|c|c|c|c|c|c|c|}
\hline \multirow[b]{2}{*}{ Seasons } & \multicolumn{5}{|c|}{ Indicators of haemo-dynamic } & \multirow[b]{2}{*}{$\begin{array}{l}\text { Expulsion } \\
\text { phase, ml.sec. }\end{array}$} & \multirow[b]{2}{*}{$\begin{array}{l}\text { Pre- expulsion } \\
\text { phase, } \mathrm{ml} \text {.sec. }\end{array}$} \\
\hline & HBR, bpm & SV, ml & MBV I/min & $E F, \%$ & Heater index & & \\
\hline 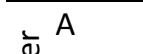 & $66.21 \pm 1.32$ & $72.95 \pm 1.35$ & $4.83 \pm 0.20$ & $59.66 \pm 0.31$ & $15.36 \pm 0.48$ & $256.62+4.20$ & $94.92 \pm 2.41$ \\
\hline 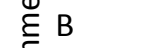 & $81.32 \pm 1.64$ & $52.02 \pm 1.48$ & $4.23 \pm 0.22$ & $43.89 \pm 0.29$ & $13.32 \pm 0.43$ & $209.40 \pm 4.12$ & $118.42 \pm 3.01$ \\
\hline$\stackrel{5}{\leftrightharpoons} P$ & $<0.001$ & $<0.01$ & $<0.05$ & $<0.001$ & $<0.01$ & $<0.01$ & $<0.001$ \\
\hline$A$ & $68.80 \pm 1.42$ & $71.34 \pm 11.88$ & 4.9110 .17 & 60.8910 .32 & $16.38 \pm 10.42$ & $257.32+4.02$ & $92.98 \pm 12.32$ \\
\hline $\bar{\xi} \mathrm{B}$ & $84.32 \pm 1.61$ & $52.80 \pm 1.96$ & $4.45 \pm 0.13$ & $48.46 \pm 0.30$ & $12,36 \pm 0.39$ & $208.40 \pm 4.20$ & $116.85 \pm 2.62$ \\
\hline$\stackrel{2}{\frac{2}{4}} P$ & $<0.001$ & $<0.01$ & $<0.05$ & $<0.001$ & $<0.001$ & $<0.001$ & $<0.001$ \\
\hline A & $69.92 \pm 1.56$ & $67.42 \pm 2.12$ & $4.71 \pm 0.18$ & $61.95 \pm 0.33$ & $18.83 \pm 0.64$ & $258.90 \pm 4.36$ & $88.26 \pm 2.30$ \\
\hline$\stackrel{ \pm}{ \pm} B$ & $88.42 \pm 1.69$ & $50.22 \pm 1.49$ & $4.44 \pm 0.17$ & $48.68 \pm 0.28$ & $14.92 \pm 0.58$ & $211.14 \pm 4.18$ & $117.30 \pm 2, .1$ \\
\hline$\sum_{3} P$ & $<0.001$ & $<0.01$ & & $<0.001$ & $<0.001$ & $<0.001$ & $<0.001$ \\
\hline A & $72.02 \pm 1.60$ & $64.92 \pm 2.02$ & $4.68 \pm 0.20$ & $58.86 \pm 0.27$ & $20.32 \pm 0.52$ & $259.20 \pm 4.15$ & $85.20 \pm 2.29$ \\
\hline$\stackrel{\infty}{\subseteq} \mathrm{B}$ & $90.76 \pm 1.70$ & $49.20 \pm 2.18$ & $4.47 \pm 0.22$ & $47.68 \pm 0.28$ & $13.67 \pm 0.49$ & $208.23 \pm 4.12$ & $112.58 \pm 2.61$ \\
\hline ㅎำP & $<0.001$ & $<0.01$ & & $<0.001$ & $<0.001$ & $<0.001$ & $<0.001$ \\
\hline
\end{tabular}

HBR - heart beats rate; SV - stroke volume; MBV - minute blood volume; EF - ejection fraction; Heater index index of myocardium contractility; A - orthostatic test in lying position; B - orthostatic test in standing position; $\mathrm{P}$ - statistical confidence.

The results, presented in table 5, actually assess students' physical and functional fitness in different seasons with the help of orthostatic test.

\section{Discussion}

We assessed influence of aggressive environmental factors on students' bloodstream system and vegetative characteristics of homeostasis in conditions of university educational process. We received new physiological data, which permit to timely correct the content of physical education and mass sports programs in conditions of individual differentiated physical education. Specific mechanisms of bloodstream in students with different adaptation abilities were found as well as correlations of cardio-vascular system's (CVS) different links and their dependence on level of vegetative activity. With it, it was important to determine admissible individual limits of applied impacts.

Values of HBR, SV under orthostatic tests changed statistically confident in all seasons that witness about sympatheticotonia. In conditions of relative rest we found no significant changes of SV and MBV. Confident shift of MBV under active orthostatic balance took place in summer and autumn. Therefore, mechanisms of SV and MBV regulations shall be studied under influence of functional tests. Optimal contractility of myocardium was observed in summer-autumn-winter. In spring it changed against the background of HBR increase. Expulsion phase (EP) of heart cycle gradually increased depending on seasons. Confident shortening of expulsion phase was observed under orthostatic test. The highest difference in positions "lying-standing" was in spring. Pre-expulsion phase (PEP) gradually decreased from summer to spring $\left(\mathrm{P}_{1}-\mathrm{P}_{4}<0.05\right)$. The highest difference between positions "lying-standing" was in winter and spring and the least - in summer and in autumn.

Coming from above presented data we can conclude that individual differentiated physical education and mass sports rendered physiological impact on the studied functions of cardio-haemo-dynamic. With it, it should be noted that there were combined changes in links of central and periphery blood circulation, blood saturation with oxygen, index of oxygen supply to tissues. Brightly expressed changes of season fluctuations were observed in indicators of integral index of status, heart beats rate, ST segment, saturation, and index of sympathetic activity, amplitude of aorta pulsation, venous age and heart index. 
Regulation of central blood stream was characterized by variability of indicators at heart and vessels' level, causing fluctuations of contractility (ejection fraction, heater index) and venous age. Regulation at level of artery-vesicular circulation sector was realized in combined way: by vegetative nervous system and by the walls of blood vessels. Besides, regulation was realized through cells, releasing vaso-active substances [13, 17]. We can assume that CVS functional state is directed to hypo- or hyper mobilization. There takes place reconstruction between links of bloodstream integral system that manifests in change of some functions' activity and in variability of activity's effectiveness as well as homeostasis passing to new level [14, 18].

\section{Conclusions}

1. Content of programs of informational, health related-sports, physical culture and prophylaxis measures (project) caused in students' groups different manifestation of speed characteristics (in bloodstream links and in its regulation).

2. Balance of sympathetic and para-sympathetic regulations of students' central and periphery bloodstream was observed in conditions of annual educational process. It depends on weather factors of seasons, examination sessions. Besides, it brings functional system of haemo-dynamic to new homeostatic indicators.

3. Weakening of nervous activity in efferent sympathetic fibers causes increase of activity in parasympathetic fibers. Reduction of sympathetic activity reduces vascular-motor tonus in resistant capacitive vessels; facilitates decrease of HBR; increases time of impulses' passing in right ventricle and contractility of atriums in orthostatic balance.

4. We found dependence of different CVS links' responsiveness on background level of its vegetative regulation.

\section{Conflict of interests}

The authors declare that there is no conflict of interests.

\section{References}

1. Aleksandrov IuI, Anokhin KV. Nejron. Obrabotka signalov. Plastichnost'. Modelirovanie [Neuron. Processing of signals. Plasticity. Simulation], Tyumen: TSU Publ.; 2008. (in Russian)

2. Guyton Arthur C, Hall John E. Guyton and Hall Textbook of Medical Physiology with Student Consult Online Access (11th ed.). Philadelphia: Elsevier Saunders.

3. Vejn AM. Vegetativnye rasstrojstva: klinika, lechenie, diagnostika [Vegetative disorders: clinic, treatment, diagnostic], Moscow: Medical News Agency; 2000. (in Russian)

4. Isaev AP, Erlikh VV, Ezhov VB. Lokal'no-regional'naia myshechnaia vynoslivost' v sisteme podgotovki $i$ adaptacii begunov $i$ lyzhnikov-gonshchikov $v$ usloviiakh ravniny i srednegor'ia [Local-regional muscular endurance in system of runners' and ski-racers' training and adaptation in conditions of plain and midlands], Chelyabinsk: South Ural State University Publishing Center; 2014. (in Russian)

5. Isaev AP, Erlikh VV. Sport i srednegor'e [Sports and midlands], Chelyabinsk: South Ural State University Publishing Center; 2013. (in Russian)

6. Isaev AP, Erlikh VV. Polifunkcional'naia mobil'nost' $i$ variabel'nost' organizma sportsmenov olimpijskogo rezerva $v$ sisteme mnogoletnej podgotovki [Polyfunctional mobility and variability of Olympic reserve sportsmen's organism in system of many years' training], Chelyabinsk: South Ural State University Publishing Center; 2010. (in Russian)

7. Noskov VB, Katov AN. Ortostaticheskaia ustojchivost' zdorovogo cheloveka pri gipogidratacii [Orthostatic balance of healthy person in conditions of dehydration]. Fiziologiia cheloveka, 1990;1:112-117. (in Russian)

8. Uilmor DzhKh, Kostill DL. Fiziologiia sporta i dvigatel'noj aktivnosti [Physiology of sports and motor functioning], Kiev: Olympic Literature; 1997. (in Russian)

9. Chereshnev VA, Iushkov BG. Patofiziologiia [Pathological physiology], Moscow: Veche; 2001. (in Russian)

10. Iansen P. ChSS, laktat i trenirovki na vynoslivost' [HBR, lactate and trainings for endurance], Murmansk: Tuloma; 2013. (in Russian)

11. Hoffman J. Physiological Aspects of Sport Training and Performance. Human Kinetics; 2002.

12. Issurin V, Blumenstein B, Lidor R, Tenenbaum G. A modem approach to high-performance training: the Block Composition concept. Oxford: Meyer Sport; 2007. 
13. Kellman M. Recovery-Stress Questionnaire for Athletes. Human Kinetics; 2001.

14. Pfutzner A, Reif M, Tunnemaann H. International and national tendencies, based on results of Olympic games in Sydney. Leis-tungssport, 2001;1.:20-36.

15. Platonov VN, Bulatova MM. Physical training. Rio de Janeiro: Sprint; 2003.

16. Platonov VN. General theory of sports training. Barselona: Paidotribo; 2002.

17. Seely R. Anatomy \& Physiology. Mc Graw Hill; 2003.

18. Thomas JR. Research Methods in Physical Activity. Human Kinetics; 2001.

19. Thoden JS. Testing aerobic power. Human Kinetics; 2001.

20. Wittenberg BA. Both hypoxia and work are required to enhance expression of myoglobin «Hypoxia reprograms and regulates myoglobin expression». Am. J. Physiol. Cell Physiol. 2009;296:390-392.

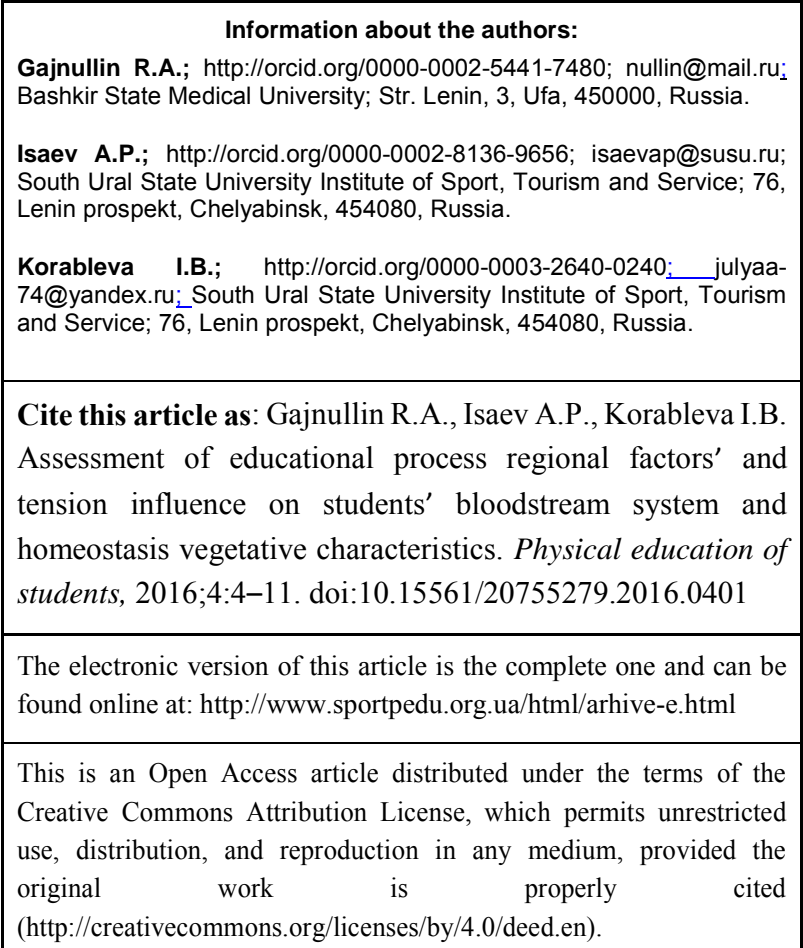

Received: 04.08.2016

Accepted: 19.08.2016; Published: 28.08.2016 